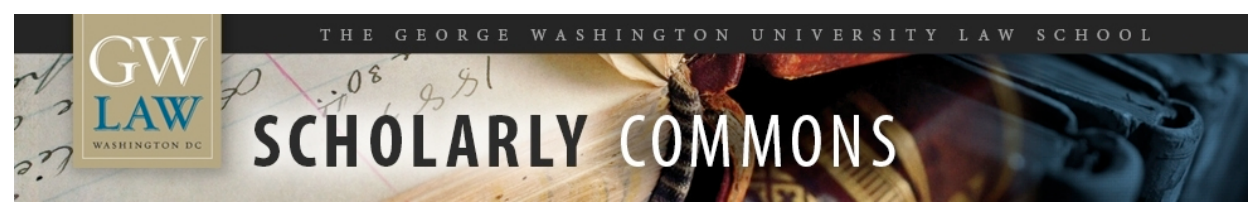

\title{
A New Approach to Voir Dire on Racial Bias
}

Cynthia Lee

George Washington University Law School, cylee@law.gwu.edu

Follow this and additional works at: https://scholarship.law.gwu.edu/faculty_publications

Part of the Law Commons

\section{Recommended Citation}

Research Paper Series, GWU Law and Lee, Cynthia, A New Approach to Voir Dire on Racial Bias (2015). Cynthia Lee, A New Approach to Voir Dire on Racial Basis, 5 U.C. IRVINE L. REV. 843 (2015). ; GWU Law School Public Law Research Paper No. 2015-63; GWU Legal Studies Research Paper No. 2015-63. Available at SSRN: http://ssrn.com/abstract $=2729432$

This Article is brought to you for free and open access by the Faculty Scholarship at Scholarly Commons. It has been accepted for inclusion in GW Law Faculty Publications \& Other Works by an authorized administrator of Scholarly Commons. For more information, please contact spagel@law.gwu.edu. 


\title{
A New Approach to Voir Dire on Racial Bias
}

\author{
Cynthia Lee*
}

Introduction .843

I. Voir Dire

A. The Process of Voir Dire

B. The Supreme Court's Jurisprudence on Voir Dire into Racial Bias.

II. Social Science Research on Race Salience

A. Implicit Bias

B. Race Salience

III. Social Science Research on Racial Perceptions of Crime and Support for Punitive Criminal Justice Policies

IV. Combating Implicit Racial Bias in the Criminal Courtroom

A. Raising Awareness of Implicit Bias Through Jury Orientation Materials

B. Raising Awareness of Implicit Bias Through Voir Dire .867

C. Possible Objections.

Conclusion

\section{INTRODUCTION}

The shooting of Michael Brown in Ferguson, Missouri on August 9, 2014 renewed debate over whether racial stereotypes about Black men as dangerous, violent criminals encourage police officers and armed civilians to shoot unarmed Black men in cases where they would not have used deadly force had the victim been White. ${ }^{1}$ Two diametrically opposed accounts of what happened emerged in

\footnotetext{
* Cynthia Lee is the Charles Kennedy Poe Research Professor of Law at The George Washington University Law School. She is the author of Murder and the Reasonable Man: Passion and Fear in the Criminal Courtroom (2003) and coauthor (with Angela Harris) of Criminal Law: Cases and Materials (3d ed. 2014). She thanks Nancy Kim, Anna Roberts, and Tania Tetlow for helpful comments on this Article. She thanks Lesliediana Jones, Lam Nguyen, and Matthew Halldorson for excellent research assistance on this Article. She thanks Micah Morris of the UC Irvine Law Review for excellent editorial assistance on this Article. She also thanks Elizabeth Moulton for administrative assistance on this Article.
}

1. I purposely capitalize the letter "B" in "Black" and "W" in "White" to acknowledge the fact 
the weeks following the shooting. Brown's friend, Dorian Johnson, who was with Brown at the time Brown was shot, claimed Officer Darren Wilson shot Brown for no reason and continued shooting even after Brown turned around with his hands in the air, trying to show the officer that he was unarmed. ${ }^{2}$ In contrast, Officer Wilson said he shot Brown in self-defense after a scuffle in which Brown shoved him into his patrol car and attempted to grab his weapon. ${ }^{3}$

Polls taken shortly after the shooting showed a racial divide in public opinion over whether the officer was justified in shooting Brown with fifty-seven percent of Blacks saying they believed the shooting was unjustified and only eighteen percent of Whites with the same opinion. ${ }^{4}$ When protests erupted in Ferguson, Missouri over the shooting, the police responded with an unusually heavy-handed display of force. ${ }^{5}$ Again, public opinion was split over whether the protesters or the police acted inappropriately. ${ }^{6}$

One question that prosecutors face in highly charged cases with racial overtones like the Ferguson case is whether to attempt to conduct voir dire into

that Black and White are socially constructed racial categories. See IAN F. HANEY LÓPEZ, WHITE BY LAW: THE LEgAL CONSTRUCTION OF RACE 9-10 (1996).

2. Eliott C. McLaughlin, What We Know About Michael Brown's Shooting, CNN (Aug. 15, 2014, 12:10 AM), http://www.cnn.com/2014/08/11/us/missouri-ferguson-michael-brown-what-we-know [http://perma.cc/SK6Y-YMZ8].

3. Julia Talanova, Support Grows for Darren Wilson, Officer Who Shot Ferguson Teen Michael Brown, CNN (Sept. 8, 2014, 7:11 AM), http://www.cnn.com/2014/08/19/us/ferguson-darren-wilsonsupport [http://perma.cc/72HL-H5MH]; see also Julie Bosman et al., Amid Conflicting Accounts, Trusting the Officer, N.Y. Times, Nov. 26, 2014, at A1 (reporting that Officer Wilson told the grand jury that Michael Brown reached into his police vehicle and fought him for his gun). An investigation into the shooting by the U.S. Department of Justice found that the physical and forensic evidence supported Officer Wilson's claim of self-defense and that the officer shot Brown as Brown was moving toward the officer. See U.S. DeP'T OF JUSTICE, REPORT REgARDing THE CRIMINAL INVESTIGATION INTO the Shooting Death of Michael Brown by Ferguson, Missouri Police OfFicer Darren WILSON 5-8 (2015).

4. Reactions to the Shooting in Ferguson, Mo., Have Sharp Racial Divides, N.Y. TimeS (Aug. 21, 2014), http://www.nytimes.com/interactive/2014/08/21/us/ferguson-poll.html. The reaction of many African Americans to the shooting likely reflected their distrust of police given a long history of antagonistic police-citizen interactions in Ferguson, Missouri. After a five-month long investigation, from September 4, 2014 to March 4, 2015, the Department of Justice found significant evidence of racial bias, both implicit and explicit, in the Ferguson Police Department and criminal justice system. U.S. Dep't of Justice, Investigation of the Ferguson Police Department 62-63, 70-78 (2015).

5. Joe Coscarelli, Why Cops in Ferguson Look Like Soldiers: The Insane Militarization of America's Police, N.Y. MAG. (Aug. 14, 2014, 12:29 PM), http://nymag.com/daily/intelligencer/2014/08/insanemilitarization-police-ferguson.html [http://perma.cc/NS5P-JPPC] (noting that the law-enforcement response to civilian protests against Michael Brown's death involved tear gas, flash grenades, and military-style rifles).

6. A YouGov poll found that forty-eight percent of Whites believed the protests were unreasonable compared to thirty-one percent of Blacks. Peter Moore, Ferguson, MO.: Racial and Political Divide over Brown Shooting, YOuGOV (Aug. 18, 2014, 8:01 AM), http://today.yougov.com/news/2014/ 08/18/ferguson-mo [http://perma.cc/N2SZ-GFBF] (referring to poll results at http://cdn.yougov .com/cumulus_uploads/document/ou4yi1g0z8/tabs_HP_police_20140817-2.pdf). The same poll found thirty-four percent of Whites believed the police response to the Ferguson protests to be reasonable compared to only sixteen percent of Blacks with the same opinion. Id. 
racial bias. ${ }^{7}$ Voir dire is the process of questioning prospective jurors to ensure that those chosen to sit on the jury will be impartial and unbiased. As Neil Vidmar and Valerie Hans explain, "[v] oir dire, a term with a French origin meaning roughly 'to see them say,' is used to denote the process whereby prospective jurors are questioned about their biases during the jury selection process . . .".8 In federal court, voir dire is generally conducted by the trial judge. ${ }^{9}$ In state court, voir dire practice varies widely depending on the jurisdiction. In most states, voir dire is conducted by both the judge and the attorneys. ${ }^{10}$

7. In the Ferguson case, since the grand jury convened by prosecutor Robert McCulloch declined to indict Officer Wilson in November 2014, prosecutors did not need to answer this question. Taylor Wofford, After Grand Jury Decides Not to Charge Darren Wilson, What's Next for Ferguson?, NEWSWEEK (Nov. 24, 2014, 9:35 PM), http://www.newsweek.com/no-charges-ferguson-michaelbrown-shooting-case-285976 [http://perma.cc/6TNQ-N4MT]. Many thought McCulloch should have let someone else handle the case because of McCulloch's strong ties to law enforcement and the fact that his father was a police officer who was killed by a Black man when McCulloch was only twelve years old. See Pema Levy, Ferguson Prosecutor Robert P. McCulloch's Long History of Siding with the Police, NEWSWEEK (Aug. 29, 2014, 6:33 AM), http://www.newsweek.com/ferguson-prosecutor-robert-pmccullochs-long-history-siding-police-267357 [http://perma.cc/ZU9A-QP9S] (“[McCulloch's] father was a St. Louis policeman killed in the line of duty by a Black man when McCulloch was 12. [McCulloch's] brother, nephew and cousin all served with the St. Louis police [department]"); see also Leigh Ann Caldwell, Concerns Arise About Prosecutor in Michael Brown Case, CNN (Aug. 20, 2014, 12:48 PM), http://www.cnn.com/2014/08/19/us/ferguson-prosecutor-mcculloch [http://perma.cc/6PSHSEXY]. After it came to light that McCulloch knew some of the witnesses he presented to the grand jury were lying, the NAACP Legal Defense Fund asked a Missouri judge to reconvene a new grand jury panel to reconsider the case. Christopher Harress, NAACP Calls for New Ferguson Grand Jury Citing Multiple Concerns with November Decision, INT’L BUS. TIMES (Jan. 6, 2015, 7:25 PM), http:// www.ibtimes.com/naacp-calls-new-ferguson-grand-jury-citing-multiple-concerns-november-decision1775386 [http://perma.cc/Z5RD-2G2E]. The judge denied the NAACP's request to convene a new grand jury. Associated Press, Judge Rejects Request for New Ferguson Grand Jury, WASH. TIMES (Jan. 21, 2015), http://www.washingtontimes.com/news/2015/jan/21/judge-rejects-request-for-new-fergusongrand-jury/.

8. Neil Vidmar \& VALERIE P. HANS, American Juries: The VERdict 87 (2007).

9. Tamara F. Lawson, Before the Verdict and Beyond the Verdict: The CSI Infection Within Modern Criminal Jury Trials, 41 LOY. U. CHI. L.J. 119, 145 (2009) (noting that in the federal system, judges ask most of the questions during voir dire, whereas in the state system, judges allow attorneys to ask most questions).

10. Maureen A. Howard, Taking the High Road: Why Prosecutors Should Voluntarily W aive Peremptory Challenges, 23 GEO. J. LeGAL ETHICs 369, 378-79 n.44 (2010) (citing Valerie P. Hans \& Alayna Jehle, Avoiding Bald Men and People with Green Socks? Other Ways to Improve the Voir Dire Process in Jury Selection, 78 CHI.-KENT L. REV. 1179, 1184 (2003)) (noting that in forty-three states, voir dire questioning is conducted by both the judge and attorneys); David B. Rottman et al., U.S. DEP'T OF JUSTICE, State Court Organization 1998, at 273-77 tbl.41 (2000), http://www.bjs.gov/content/pub/pdf/ sco98.pdf [http://perma.cc/2SMK-7ETA] (listing four states_Connecticut, North Carolina, Texas, and Wyoming-in which attorneys only conduct voir dire, listing seven states-Arizona, California, Delaware, Illinois, Massachusetts, New Hampshire, and New Jersey-in which judges only conduct voir dire, and noting that both attorneys and judges conduct voir dire in the remaining states). In Missouri, judges usually allow the attorneys to ask the questions during jury selection, but the judge may, at her discretion, conduct some or all of the voir dire herself. Your Missouri Courts, TRIAL JUDGES CRIMINAL BENCHBOOK JS 7.8-.9 (Kelly Broniec et al. eds., 2007), http://www.courts.mo.gov/ hosted/resourcecenter/TJCB\%20Published\%20April\%208.2011/TJBB.htm\#CH_07_JurySelect_2d_ files/CH_07_JurySelect_2d.htm (noting that voir dire is done first by the counsel for the state and then by the counsel for the defendant $\left(\int 7.8\right)$, but also noting that in some instances-at the court's 
It is important to note that racial bias is not unique to any particular group. While it is often assumed that racial bias means bias in favor of Whites and against Blacks, racial bias can cut in many different ways. In the Ferguson case, for example, those who believed Michael Brown was shot when he had his hands up before the Department of Justice's investigation into the shooting was completed ${ }^{11}$ may have assumed Officer Wilson was lying when he claimed self-defense because of stereotypes about White police officers as racist individuals. At the same time, those who believed the officer's account of what happened before knowing all of the facts relating to the shooting may have assumed Michael Brown was acting in a threatening way because of stereotypes about Black men.

The Supreme Court has addressed the question of voir dire into racial bias in only a handful of cases. All of these cases dealt with the issue of whether a criminal defendant has the right to have prospective jurors questioned on racial bias, and the last time the Court dealt with this issue was in 1986, more than twenty-five years ago.

Reasonable minds can disagree as to whether it is good trial strategy to voir dire prospective jurors on racial bias. Perhaps the most common view is that reflected by Albert Alschuler, who suggested over twenty-five years ago that voir dire into racial bias would be "minimally useful."12 Alschuler argued that asking a prospective juror whether he would be prejudiced against the defendant because of the defendant's race would be patronizing and offensive. ${ }^{13} \mathrm{He}$ also argued that no prospective juror would admit to racial bias, even if he was in fact prejudiced against members of a particular racial group. ${ }^{14}$

In this Article, I rely on empirical research on implicit bias to challenge Alschuler's view that voir dire into racial bias would be of minimal benefit to an attorney concerned about such bias. This research suggests that for an attorney concerned that racial stereotypes about the defendant, the victim, or a witness might affect how the jury interprets the evidence, voir dire into racial bias can be extremely helpful. Calling attention to implicit racial bias can encourage jurors to view the evidence without the usual preconceptions and automatic associations involving race that most of us make. While I agree with Alschuler that a simple, close-ended question like, "Are you going to be biased against the defendant because of his race?" is unlikely to be helpful, I believe that a series of open-ended questions

discretion - the judge can conduct some or all of the voir dire by herself ( $\left.\int 7.9\right)$ ); Michael L. Matula \& G. Nicole Hininger, The Law of Jury Selection in Missouri State Courts, 66 J. Mo. BAR 136 (2010), https:/ / www.mobar.org/uploadedFiles/Home/Publications/Journal/2010/05-06/The\%20Law\%20of\%20 Jury $\% 20$ Selection $\% 20 \mathrm{in} \% 20$ Missouri $\% 20$ State $\% 20$ Courts.pdf (noting that all parties have the opportunity to question jurors to expose juror bias or prejudice).

11. See U.S. DEP'T OF JUSTICE, supra note 3, at 5-8 (2015) (finding that the physical and forensic evidence supported Officer Wilson's claim of self-defense).

12. Albert W. Alschuler, The Supreme Court and the Jury: Voir Dire, Peremptory Challenges, and the Review of Jury Verdicts, 56 U. CHI. L. REV. 153, 160 (1989).

13. Id. at 161 .

14. Id. at 160 ("One doubts that Lester Maddox, Orville Faubus, George Wallace, Theodore Bilbo or anyone else would have responded to the proposed question by confessing a bias .....”). 
educating jurors about implicit bias and encouraging them to reflect upon whether and how implicit racial bias might affect their ability to even-handedly consider the evidence can be beneficial in helping to ensure a truly impartial jury.

My Article proceeds in four parts. In Part I, I provide an overview of the process of voir dire and review the Supreme Court's jurisprudence on voir dire into racial bias. In Part II, I examine social science research that helps answer the question whether it is a good idea to conduct voir dire into racial bias. Some of this research relates to the Implicit Association Test (IAT), an online test that measures implicit bias by comparing response times to selected words and images. Additionally, however, a wealth of less familiar empirical research on race salience conducted over the past decade indicates that calling attention to race can motivate jurors to treat Black and White defendants equally, whereas not highlighting race may result in jurors tending to be more punitive and less empathetic towards Black defendants than they might otherwise be without such attention.

In Part III, I examine a few recent studies calling into question whether making race salient is a good idea. These studies indicate that when White individuals perceive extreme racial differences in the prison population (i.e., when they believe there are many more Blacks and Latinos than Whites in prison), they are more likely to support punitive criminal justice policies than when they perceive that the proportion of minorities in prison is not so large. I analyze these studies and conclude that, while they may appear at first glance to contradict the race salience research, they do not in fact undermine that research.

In Part IV, I turn to the question of what steps can be taken to combat implicit racial bias in the criminal courtroom. I argue that in light of the social science research on implicit bias and race salience, it is best for an attorney concerned about racial bias to confront the issue of race head on during jury selection. Voir dire can be used to both educate prospective jurors about the concept of implicit bias and help them to become aware of their own implicit biases. It makes sense to address the possibility of implicit racial bias early on, rather than waiting until just before the jury deliberates, as it may be too late by then to undo its effects.

\section{VOIR DIRE}

It is often said that a trial is won or lost when the jury is selected. ${ }^{15}$ This is because "jurors bring to the courtroom biases and predispositions which largely determine the outcome of the case."16 The process of voir dire presents an opportunity for the attorneys to influence who ends up sitting on the jury, at least in jurisdictions where attorney voir dire is permitted.

In this Part, I first discuss the process of voir dire and its role in jury selection.

15. Cynthia Lee, Making Race Salient: Trayvon Martin and Implicit Bias in a Not Yet Post-Racial Society, 91 N.C. L. REV. 1557,1590 n.223 (2013).

16. Margaret Covington, Jury Selection: Innovative Approaches to Both Civil and Criminal Litigation, 16 ST. MARY'S L.J. 575, 576 (1985). 
I also examine the benefits of attorney voir dire over judge-dominated voir dire. I then discuss the Supreme Court's jurisprudence on voir dire into racial bias.

\section{A. The Process of Voir Dire}

"Voir dire is the process of questioning prospective jurors about their qualifications to serve on the jury panel to decide the case."17 In federal court, voir dire is usually conducted by the judge. ${ }^{18}$ In state court, jury selection procedures vary widely with judge-dominated voir dire the practice in seven states, attorneydominated voir dire the practice in four states, and a mix of judge and attorney questions in the remaining state courts. ${ }^{19}$ Some courts allow the attorneys to propose questions that are then given to prospective jurors in the form of a written questionnaire. ${ }^{20}$

According to one source, jury selection in felony cases takes an average of 3.6 to 3.8 hours. ${ }^{21}$ During the process of jury selection, the parties are given the opportunity to strike an unlimited number of prospective jurors for cause. A "for cause" challenge will be granted if the judge finds that the party has articulated a good reason that the juror should not serve, such as an inability to be impartial or a prior relationship with the defendant, the defense attorney, the prosecutor, the judge, or one of the witnesses. ${ }^{22}$ Each side is also given a set number of peremptory challenges, ${ }^{23}$ which can be used to strike a prospective juror for any reason or no reason at all, as long as the reason for striking the prospective juror is not based on the individual's race or gender. ${ }^{24}$

In order to guard against the possibility that attorneys may use their peremptory challenges to strike prospective jurors based on their race, the Court in Batson v. Kentucky ${ }^{25}$ established a three-part framework much like the three-part framework used in the Title VII context to determine whether an individual has

17. Mark W. Bennett, Unraveling the Gordian Knot of Implicit Bias in Jury Selection: The Problems of Judge-Dominated Voir Dire, the Failed Promise of Batson, and Proposed Solutions, 4 HARV. L. \& POL'Y REV. 149, 158 (2010).

18. Lawson, supra note 9, at 145.

19. Rottman et al., supra note 10, at 273-77.

20. Roxanne Barton Conlin \& Gretchen Jensen, What, Me? Prejudiced? Absolutely Not!, TRIAL, Dec. 2000, at 20, 22.

21. Collin P. Wedel, Note, Twelve Angry (and Stereotyped) Jurors: How Courts Can Use Scientific Jury Selection to End Discriminatory Peremptory Challenges, 7 STAN. J. C.R. \& C.L. 293, 315 (2011).

22. VIDMAR \& HANS, supra note 8 , at 87 ("A 'challenge for cause' is an assertion by one of the lawyers that a potential juror is not impartial.").

23. For example, in federal court, a defendant charged with a felony is given ten peremptory challenges, and the prosecutor is given six peremptory challenges. FED. R. CRIM. P. 24(b)(2). If the defendant is in federal court and charged with a misdemeanor, both the defendant and the prosecutor are given three peremptory challenges. (b)(3). In a federal capital case, both sides get twenty peremptory challenges. (b)(1).

24. J.E.B. v. Alabama, 511 U.S. 127 (1994) (forbidding peremptory challenges based on gender); Batson v. Kentucky, 476 U.S. 79 (1986) (prohibiting peremptory challenges based on race).

25. Batson, 476 U.S. at 79. 
been denied a job on the basis of unlawful discrimination. ${ }^{26}$ Under the Batson framework, if one party believes the other party has used a peremptory strike to remove a juror because of the juror's race, that party may assert a Batson challenge. ${ }^{27}$ The challenger must first set forth a prima facie case of intentional discrimination. ${ }^{28}$ Under the original Batson framework, a defendant who asserted a Batson challenge could establish a prima facie case of purposeful discrimination in the selection of the jury by showing "that he [was] a member of a cognizable racial group . . . and that the prosecutor [had] exercised peremptory challenges to remove from the venire members of the defendant's race." 29 Once the defendant showed that these facts and any other relevant circumstances raised an inference that the opposing party used its peremptory challenges to exclude individuals from the jury on account of their race, ${ }^{30}$ the burden shifted to the opposing party to proffer a race-neutral reason for the strike. ${ }^{31}$ After a race-neutral reason was proffered by the party opposing the Batson challenge, the trial court had to decide whether the challenger has met its burden of proving purposeful discrimination. ${ }^{32}$ In J.E.B. v. Alabama, the Court extended Batson to forbid peremptory challenges based on gender. ${ }^{33}$ At least one lower court has gone further, applying Batson to peremptory challenges based on sexual orientation. ${ }^{34}$

26. Under the three-part framework established by the Court in McDonnell Douglas Corp. v. Green, the employee must first establish a prima facie case of unlawful discrimination by a preponderance of the evidence. McDonnell Douglas Corp. v. Green, 411 U.S. 792, 802 (1973). The employee can establish a prima facie case by showing (1) he belongs to a racial minority; (2) he applied and was qualified for a job the employer was trying to fill; (3) though qualified, he was rejected; and (4) thereafter the employer continued to seek applicants with complainant's qualifications. Id. Once the employee establishes a prima facie case, the burden shifts to the employer to rebut this prima facie case by articulating a legitimate, nondiscriminatory reason for the employee's rejection. Id. The employee can prevail only if he can show that the employer's response is merely a pretext for behavior actually motivated by discrimination. Id. at 798 .

27. Because Batson involved a defendant's challenge to a prosecutor's peremptory challenge, its holding left open the question whether a prosecutor could assert a challenge against a defendant if he believed the defendant was exercising its peremptory challenges in a racially discriminatory manner. In 1992, the Court answered this question in the affirmative, applying Batson to criminal defendants. Georgia v. McCollum, 505 U.S. 42, 46-48 (1992); see also Edmonson v. Leesville Concrete Co., 500 U.S. 614, 618-19 (1991) (extending Batson to civil litigants).

28. Batson, 476 U.S. at 96.

29. Id. Subsequently, the Court broadened the Batson framework to include challenges based on ethnicity, see Hernandez v. New York, 500 U.S. 352 (1991), and later gender, see J.E.B. v. Alabama, 511 U.S. 127 (1994).

30. Id.

31. Id. at 97. The Court, however, has made it fairly easy for the opposing party to rebut the challenge, finding it is not necessary that the opposing party's race-neutral explanation be minimally persuasive or even plausible at stage two of the Batson inquiry. Purkett v. Elem, 514 U.S. 765, 768 (1995) ("The Court of Appeals erred by ... requiring that the justification tendered at the second step be not just neutral but also at least minimally persuasive, i.e., a 'plausible' basis for believing that 'the person's ability to perform his or her duties as a juror' will be affected.”).

32. Batson, 476 U.S. at 98.

33. J.E.B. v. Alabama, 511 U.S. 127 (1994).

34. SmithKline Beecham Corp. v. Abbott Labs., 740 F.3d 471, 476 (9th Cir. 2014). 
While Batson was well intended, it has not proven to be very effective. ${ }^{35}$ Attorneys facing Batson challenges have been able to survive these challenges by proffering fairly implausible "race-neutral" reasons for their strikes. For example, in one case, a prosecutor who faced a Batson challenge from a Black defendant charged with importing heroin proffered two ostensibly race-neutral reasons for striking a Black woman from the jury. ${ }^{36}$ First, the prosecutor noted that the prospective juror was a postal employee and said that it was the U.S. Attorney's Office's general policy not to have postal employees on the jury. ${ }^{37}$ When pressed by the defense attorney, the prosecutor backed down and admitted that the office did not have such a policy and proffered a second reason for the strike. ${ }^{38}$ The prosecutor then suggested that because the prospective juror was a single parent who rented an apartment in an urban area, she "may be involved in a drug situation where she lives." 39 The judge accepted this second explanation as a race-neutral reason for the strike and denied the defense's Batson objection. ${ }^{40}$

In another case, the government used five of its six peremptory challenges to strike Black jurors. ${ }^{41}$ When the defendant, a Black man, asserted a Batson challenge, one of the race-neutral reasons proffered by the government for striking a Black female from the jury was that her name, Granderson, closely resembled that of a defendant, Anthony Grandison, in a previous case tried by the same prosecutor. ${ }^{42}$ Even though that case was completely unrelated to the case at hand and therefore the fact that the prospective juror's name was similar to the name of a defendant in a completely unrelated case would have had no bearing on the prospective juror's ability to be fair and impartial, the Court of Appeals agreed with the trial court that this was a neutral and nonpretextual reason for the strike and affirmed the defendant's conviction. ${ }^{43}$

In United States $v$. Romero-Reyna, the defendant, a Hispanic man charged with possession of marijuana and heroin with intent to distribute, challenged the government's use of its peremptory challenges against six prospective jurors of Hispanic origin. ${ }^{44}$ The prosecutor proffered as a race-neutral reason for striking one of the individuals who worked as a pipeline operator that he had a "P" rule in which

35. Professor Jean Montoya surveyed prosecutors and criminal defense attorneys and found that most thought Batson was of limited effectiveness in eliminating racial discrimination in jury selection in large part because of the ease with which an attorney can come up with a race-neutral reason for the strike. Jean Montoya, The Future of the Post-Batson Peremptory Challenge: Voir Dire by Questionnaire and the "Blind” Peremptory, 29 U. MiCH. J.L. REFORM 981, 1006 (1996).

36. United States v. Uwaezhoke, 995 F.2d 388 (3d Cir. 1993).

37. Id. at 390-91.

38. Id. at 391 .

39. Id.

40. Id.

41. United States v. Tindle, 860 F.2d 125, 128 (4th Cir. 1988).

42. Id. at 129 .

43. $I d$.

44. United States v. Romero-Reyna, 889 F.2d 559, 560 (5th Cir. 1989). 
he never accepted jurors whose occupations began with a "P." 45 The trial court accepted this explanation as nonpretextual and rejected the defendant's Batson challenge. ${ }^{46}$ On remand, the prosecutor repeated adherence to his "P" rule, but added that he had been informed that marijuana use by pipeline operators was prevalent. ${ }^{47}$ This time, the trial court rejected the prosecutor's "P" rule as a legitimate basis for the strike, noting that several other members of the venire had occupations beginning with the letter "P" and had not been struck by the prosecutor. ${ }^{48}$ Nonetheless, the trial court found that the newly added explanation was race-neutral and not a pretextual reason for the strike and rejected the defendant's Batson challenge again. ${ }^{49}$

Another problem is that the attorney exercising the challenged strike may not even be aware that she would not have struck the prospective juror if that individual had been of another race. As Antony Page explains, an attorney may be unaware that she has relied on racial stereotypes in forming her opinions about the prospective juror. ${ }^{50}$ When asked to provide a race-neutral reason for the strike, the attorney may sincerely believe that she struck the prospective juror for reasons not related to the juror's race, even though implicit racial bias may have in fact influenced the attorney's perceptions of the individual. ${ }^{51}$ "By the time the lawyer exercises the peremptory challenge, stereotypes may have thoroughly affected her observation and interpretation of the information upon which she makes her decision." 52 In light of these and other problems with the Batson framework, critics of Batson have argued that it would be best to simply eliminate the peremptory challenge altogether and force attorneys to take the first twelve individuals in the jury box unless the attorneys can articulate reasons to challenge those individuals for cause. ${ }^{53}$

Regardless of whether peremptory challenges continue to exist in our criminal justice system, a critical question remains: which legal actor-the judge or the attorney-should conduct voir dire? Empirical research suggests that judgedominated voir dire is less effective at discovering juror bias than attorney voir dire because prospective jurors often give what they think is the socially desirable

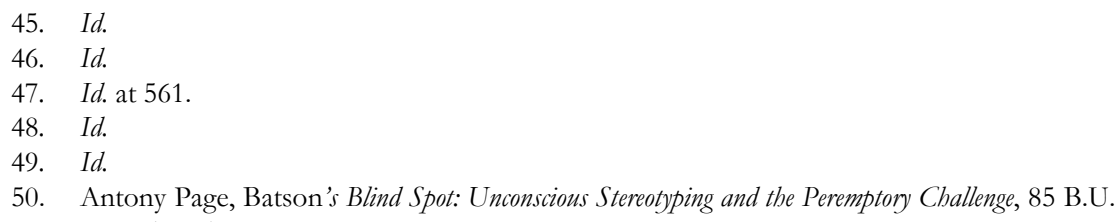
L. REV. 155, 228 (2005).

51. Id.

52. Id.

53. See Raymond J. Broderick, Why the Peremptory Challenge Should be Abolished, 65 TEMP. L. REV. 369, 420-23 (1992); Theodore McMillian \& Christopher J. Petrini, Batson v. Kentucky: A Promise Unfulfilled, 58 UMKC L. REV. 361, 374 (1990); see also Batson v. Kentucky, 476 U.S. 79, 103 (1986) (Marshall, J., concurring) (opining that the only way to stop the discriminatory use of the peremptory challenge is to completely abolish peremptory challenges). 
response when the judge is asking the questions. ${ }^{54}$ There are other reasons why a trial court should allow the attorneys to conduct voir dire, particularly when the case involves the possibility of racial bias. As Judge Mark Bennett notes, attorneys usually know the case better than the trial judge, and therefore "are in the best position to determine how explicit and implicit biases among potential jurors might affect the outcome." 55 Attorneys also have more of an incentive than the trial judge to use jury consultants and other resources "to develop voir dire strategies to address both explicit and implicit biases of prospective jurors." 56 'This is because attorneys need as much information as possible about the prospective jurors in order to know which prospective jurors would have difficulty being impartial and should be stricken from the jury. ${ }^{57}$

\section{B. The Supreme Court's Jurisprudence on Voir Dire into Racial Bias}

The U.S. Supreme Court has addressed the question of whether a criminal defendant has a right to question prospective jurors on the issue of racial bias in only a handful of cases. Not surprisingly, the Court has gone back and forth on this issue.

Initially, the Court was sympathetic to the idea that a criminal defendant has a constitutional right to question prospective jurors about racial bias. In 1931, the Court reversed a Black defendant's murder conviction where the trial judge had refused a defense request to interrogate the venire on racial prejudice. ${ }^{58}$ In Aldridge v. United States, a Black man charged with the murder of a White police officer was convicted of first-degree murder and sentenced to death. ${ }^{59}$ The trial judge had refused a defense request to question prospective jurors on whether they had any racial prejudice based on the fact that the defendant was Black and the deceased was White. ${ }^{60}$ The Supreme Court reversed the conviction, stating that fairness demands that inquiries into racial prejudice be allowed. ${ }^{61}$ In response to the lower court's suggestion that such inquiry was unnecessary since African Americans were afforded the same rights and privileges as Whites, such as the right to practice law and the right to serve on juries, ${ }^{62}$ the Court said, "Despite the privileges accorded to the negro, we do not think that it can be said that the possibility of such prejudice

54. See Bennett, supra note 17, at 160; Susan E. Jones, Judge-Versus Attorney-Conducted Voir Dire: An Empirical Investigation of Juror Candor, 11 LAW \& HUM. BEHAV. 131, 143 (1987) (finding that prospective jurors respond more candidly and are less likely to give what they think is the socially desirable response when attorneys are asking the questions during voir dire than when the judge is asking questions).

55. Bennett, supra note 17 , at 160 .

56. Id.

57. J.E.B. v. Alabama, 511 U.S. 127, 154 (1994) (Kennedy, J., concurring) (“[P]reventing bias .... lies at the very heart of the jury system." (citations omitted)).

58. Aldridge v. United States, 283 U.S. 308 (1931).

59. Id. at 309 .

60. Id. at $310-11$.

61. Id. at 313 .

62. Id. at 316 (McReynolds, J., dissenting). 
is so remote as to justify the risk in forbidding the inquiry." ${ }^{33}$ Noting "[t]he argument is advanced on behalf of the government that it would be detrimental to the administration of the law in the courts of the United States to allow questions to jurors as to racial or religious prejudices," 64 the Aldridge Court concluded, "We think that it would be far more injurious to permit it to be thought that persons entertaining a disqualifying prejudice were allowed to serve as jurors and that inquiries designed to elicit the fact of disqualification were barred." ${ }^{65}$

The Court did not revisit the question of whether a criminal defendant has a right to require the trial judge to question prospective jurors on racial bias until 1973, more than forty years later. In Ham v. South Carolina, a case involving a Black civil rights activist charged with possession of marijuana, the Court again sided with the defendant, holding that a trial judge's refusal to question prospective jurors as to possible racial prejudice violated the defendant's constitutional rights. ${ }^{66}$ This time, the Court went further than it had in Aldridge v. United States and expressly grounded its decision in due process, holding that "the Due Process Clause of the Fourteenth Amendment requires that ... the [defendant] be permitted to have the jurors interrogated on the issue of racial bias." ${ }^{\prime 67}$ The Ham Court reaffirmed the trial court's discretion to conduct voir dire in the manner it thinks is best, noting that the trial judge is "not required to put the question in any particular form, or to ask any particular number of questions on the subject, simply because requested to do so by [the defendant]." 68 It also limited the right in controversy to questioning regarding possible bias to racial bias, refusing to require the trial court to question prospective jurors regarding bias against persons with beards even though the defendant, who sported a beard, had requested such voir dire. ${ }^{69}$

A mere three years later, the Court started backtracking from its support for voir dire into racial bias. In Ristaino $v$. Ross, the Court held that the mere fact that the defendant is Black and the victim is White is not enough to trigger the constitutional requirement that the trial court question prospective jurors about racial prejudice. ${ }^{70}$ The defendants in Ristaino v. Ross were three Black men on trial for armed robbery, assault and battery by means of a dangerous weapon, and assault with intent to murder two White security guards. ${ }^{71}$ Defendant Ross requested that the trial judge ask prospective jurors the following question: "Are there any of you who believe that a White person is more likely to be telling the truth than a Black person?'72 The trial court not only refused to ask this particular question, it failed

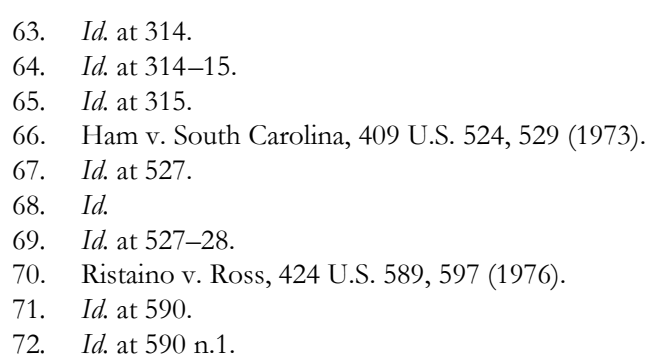


to make any reference to race when giving jurors an overview of the facts of the case and when questioning the jurors about possible bias or prejudice for or against either of the defendants or the victim. ${ }^{73}$ The jury convicted the defendants on all counts. ${ }^{74}$

In holding that the trial court did not err in refusing to question the venire on racial bias, the Court attempted to distinguish the case before it from Ham v. South Carolina. Somewhat unconvincingly, the Court explained that racial issues were "inextricably bound up with the conduct of the trial" in Ham because Ham, who had a reputation as a civil rights activist, claimed that he had been framed because of his civil rights work. ${ }^{75}$ The Ristaino Court continued, "The mere fact that the victim of the crimes alleged was a White man and the defendants were Negroes was less likely to distort the trial than were the special factors involved in Ham."76 The Court then established what some have called a "special circumstances" rule: a defendant has a constitutional right to have prospective jurors questioned on racial bias only if the circumstances of the case suggest a "significant likelihood" of prejudice by the jurors. ${ }^{77}$

Even though the Ristaino Court refused to find a due process violation in the trial court's failure to question jurors on racial bias, it did acknowledge the usefulness of asking questions on racial bias as a prudential matter. "Although we hold that voir dire questioning directed to racial prejudice was not constitutionally required, the wiser course generally is to propound appropriate questions designed to identify racial prejudice if requested by the defendant." 78 The Court indicated that had the case been tried in federal court, it would have used its supervisory power to require the trial court to ask prospective jurors questions on racial bias. ${ }^{79}$

In 1981, the Court revisited the issue of voir dire into racial bias in a case involving a defendant of Mexican descent. The defendant in Rosales-Lopez v. United States was charged with smuggling undocumented Mexican immigrants into the United States. ${ }^{80}$ The defendant requested that prospective jurors be asked the following questions: "Would you consider the race or Mexican descent of Humberto Rosales-Lopez in your evaluation of this case? How would it affect

73. Id. at 592 nn.3-4.

74. Id. at 593 .

75. Id. at $596-97$.

76. Id. at 597 .

77. Id. at 596-97; see also Laura A. Giantris, The Necessity of Inquiry into Racial Bias in Voir Dire, The Maryland Survey: 1994-1995, 55 MD. L. REV. 615, 629 (1996). Giantris discusses Hill v. State, a Maryland decision in which the Maryland Court of Appeals held that the trial court's refusal to question the venire on racial or ethnic bias constituted constitutional error and concludes that "[a]s a result of Hill, Maryland criminal defendants no longer must meet the burdensome 'special circumstances' test as enunciated in Thornton and Rosales-Lopez:" Id.; see also Barry P. Goode, Religion, Politics, Race, and Ethnicity: The Range and Limits of Voir Dire, 92 KY. L.J. 601, 672 (2004) ("Ristaino established a 'special circumstances' rule: the Constitution only requires a court to allow defendants to ask questions designed to elicit racial prejudice when the special circumstances of a case indicate a significant likelihood of prejudice by the jurors.').

78. Ristaino, 424 U.S. at 597 n.9.

79. Id.

80. Rosales-Lopez v. United States, 451 U.S. 182 (1981). 
you?" 81 The trial judge did not pose either of these questions to the prospective jurors, nor did he pose any questions specifically addressed to possible prejudice against the defendant because of his race or ethnicity. ${ }^{82}$ The trial judge instead asked the following questions of prospective jurors: "Do any of you have any feelings about the alien problem at all?"; and "Do any of you have any particular feelings one way or the other about aliens or could you sit as a fair and impartial juror if you are called upon to do so?"83

In considering defendant Rosales-Lopez's appeal, the Supreme Court started by discussing the importance of voir dire, noting that "[v] oir dire plays a critical function in assuring the criminal defendant that his Sixth Amendment right to an impartial jury will be honored." ${ }^{84}$ The Court observed that lack of adequate voir dire impairs the trial court's ability to remove jurors who cannot act impartially. ${ }^{85} \mathrm{Next}$, the Court noted that "federal judges have been accorded ample discretion in determining how best to conduct the voir dire." 86 This is due to the fact that the responsibility to impanel an impartial jury lies with the trial judge. ${ }^{87}$ Additionally, the trial judge is able to see the prospective jurors and their responses, both verbal and nonverbal, to the questions posed to them during voir dire. ${ }^{88}$

The Court next distinguished between questions directed at the discovery of racial prejudice that are constitutionally mandated and questions directed at the discovery of racial prejudice that are required of federal courts as a matter of the Court's supervisory authority over the federal courts. ${ }^{89}$ The Court then established a new nonconstitutional rule for federal courts, holding that federal courts must inquire into racial prejudice "when requested by a defendant accused of a violent crime and where the defendant and the victim are members of different racial or ethnic groups." ${ }^{\circ 0}$ In all other cases, the Court explained, reversible error will occur only when the circumstances of the case "indicate that there is a reasonable possibility that racial or ethnic prejudice might have influenced the jury." ${ }^{\prime 1}$ Because Rosales-Lopez was charged with smuggling, not a crime of interracial violence, the trial court was not required to ask questions directed at racial prejudice even though requested to do so by the defense unless there was a reasonable possibility that racial

81. Id. at 185 .

82. Id.

83. Id. at 186. It could be argued that the trial court's use of the word "alien" to describe RosalesLopez encouraged the jurors to be biased against Rosales-Lopez. The word "alien," which is used to refer to one who is an immigrant to the United States, conjures up images of aliens from outer space. Because of this, many progressives use the phrase "undocumented immigrant" rather than "illegal alien."

84. Id. at 188 .

85. Id.

86. Id. at 189 .

87. Id.

88. Id.

89. Id. at 190 .

90. Id. at 196 .

91. Id. at 191. In other words, in all other cases, the special circumstances rule established in Ristaino v. Ross would control. 
or ethnic prejudice influenced the jury. ${ }^{92}$ The Court did not believe such a possibility existed in this case. ${ }^{93}$

While Rosales-Lopez may not have been happy with the Supreme Court's decision since the Court affirmed his conviction, the decision was partially good news for future defendants, as it established a new defense-friendly rule-albeit one that leaves discretion in the trial court's hands-for defendants seeking voir dire into racial bias in federal courts. In federal cases involving a defendant and a victim of different races or ethnicities and a crime of violence, the trial court should as a prudential matter conduct voir dire into racial prejudice if the defense requests that it do so. ${ }^{94}$

In 1986, the Court addressed the issue of a defendant's right to have prospective jurors questioned on racial prejudice for the last time to date..$^{95}$ In Turner v. Murray, Willie Lloyd Turner, a Black man, was charged with capital murder and other crimes after fatally shooting a White jewelry store owner with a sawed off shotgun in front of a police officer and three witnesses. ${ }^{96}$ Apparently, Turner became upset with the store owner after learning that he had triggered a silent alarm to summon the police to the store. ${ }^{97}$

Prior to jury selection, Turner's attorney submitted to the trial judge a list of questions that he wished to ask the venire, including the following question: "The defendant, Willie Lloyd Turner, is a member of the Negro race. The victim, W. Jack Smith, Jr., was a White Caucasian. Will these facts prejudice you against Willie Lloyd Turner or affect your ability to render a fair and impartial verdict based solely on the evidence?" 98 The trial court refused to ask this question, instead asking the venire the more generic question "whether any person was aware of any reason why he could not render a fair and impartial verdict." 99 Everyone on the venire responded to this question in the negative. ${ }^{100}$ At the time they were asked this question, the prospective jurors did not know that the victim was White. ${ }^{101}$ Eight

92. Id. at 192.
93. Id. at 193.
94. Id. at 192.
95. The Court has mentioned voir dire on racial bias in other cases, but this was not the main issue in those cases. See, e.g., Warger v. Shauers, 135 S. Ct. 521, 529 n.3 (2014). The court held that a plaintiff in a personal injury suit may not use a juror affidavit detailing alleged juror dishonesty to get a new trial while noting in a footnote, "There may be cases of juror bias so extreme that, almost by definition, the jury trial right has been abridged. . . . We need not consider the question, however, for those facts are not presented here." Id.; see also, e.g., Mu’Min v. Virginia, 500 U.S. 415, 422-24 (1991) (finding no error in trial court's refusal to further question prospective jurors about news reports to which they had been exposed while discussing cases involving voir dire into racial bias as examples of state cases on the extent of voir dire examination).

96. Turner v. Murray, 476 U.S. 28, 29-30 (1986).

97. Id. at 30 .

98. Id. at $30-31$.

99. Id. at 31 .

100. Id.

101. Id. 
Whites and four Blacks were selected to serve on the jury. ${ }^{102}$ The jury found the defendant guilty of all charges, and after a separate sentencing hearing, recommended that Turner be sentenced to death. ${ }^{103}$

Turner appealed his death sentence, which the Supreme Court reversed.104 The Court started by reaffirming what it stated in Ristaino: the mere fact that the defendant is Black and the victim is White is not a special circumstance of constitutional significance. ${ }^{105}$ The Court then distinguished this case from Ristaino, noting that in addition to the fact that Turner was Black and his victim was White, Turner was charged with a capital offense. ${ }^{106}$ The Court explained why this one fact mattered so much. The jury in a capital case, the Court explained, has an enormous amount of discretion. ${ }^{107}$ First, the capital jury must decide whether aggravating factors merit putting the defendant to death. The jury must decide, for example, whether the defendant is likely to commit future violent acts, or whether his crime was "outrageously or wantonly vile, horrible or inhuman in that it involved torture, depravity of mind or an aggravated battery to the victim." 108 Additionally, "the [capital] jury must consider any mitigating evidence offered by the defendant."109

Next, the Court exhibited an amazing amount of prescience in its recognition of the concept of implicit racial bias. Even though Turner was decided in 1986, almost thirty years ago, the Court at that time realized the "unique opportunity for racial prejudice to operate but remain undetected": 110

[A] juror who believes that Blacks are violence prone or morally inferior might well be influenced by that belief in deciding whether petitioner's crime involved the aggravating factors specified under Virginia law. Such a juror might also be less favorably inclined toward petitioner's evidence of mental disturbance as a mitigating circumstance. More subtle, less consciously held racial attitudes could also influence a juror's decision in this case. Fear of Blacks, which could easily be stirred up by the violent facts of petitioner's crime, might incline a juror to favor the death penalty. ${ }^{111}$

The Turner Court noted that in cases like the one before it where the defendant was charged with a crime of violence and the defendant and victim were of different races, there was a real risk that racial prejudice might infect the proceeding and improperly lead to a death sentence. ${ }^{112}$ "The risk of racial prejudice infecting a capital sentencing proceeding is especially serious in light of the complete finality

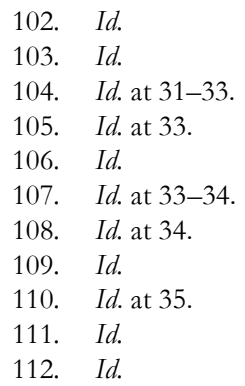


of the death sentence." 113 The Court found the risk that racial prejudice may have infected Turner's capital sentencing "unacceptable in light of the ease with which that risk could have been minimized."114 In the Court's view, the trial judge could have minimized this risk by questioning prospective jurors on racial prejudice but refused to do so. ${ }^{115}$ The Court concluded by holding that "a capital defendant accused of an interracial crime is entitled to have prospective jurors informed of the race of the victim and questioned on the issue of racial bias." 116 The Court made clear that "the trial judge retains discretion as to the form and number of questions on the subject." 117 Moreover, "a defendant cannot complain of a judge's failure to question the venire on racial prejudice unless the defendant has specifically requested such an inquiry." 118

Turner thus established a constitutional right to voir dire into racial bias in all capital cases in which the defendant is charged with an interracial crime of violence, as long as the defendant specifically requests such voir dire. ${ }^{119}$ Oddly, however, the Court limited its holding by reversing only the death sentence Turner received, not his guilty conviction. ${ }^{120}$ Even though the twelve jurors who voted to have Turner executed were the same jurors who found him guilty, the Court refused to vacate Turner's conviction. The Court explained:

At the guilt phase of petitioner's trial, the jury had no greater discretion than it would have had if the crime charged had been noncapital murder.

Thus, with respect to the guilt phase of petitioner's trial, we find this case to be indistinguishable from Ristaino, to which we continue to adhere. ${ }^{121}$

The problem with this reasoning is that Ristaino is distinguishable from Turner. Ristaino was never at risk of being put to death, but Turner was. If Turner's jury had not convicted him in the first place, he would not have been at risk of being executed. Moreover, if a juror's racial beliefs might influence her to see the defendant as more violent and dangerous, and lead that juror to more readily accept evidence of aggravating factors and discount evidence of mitigating factors, then those same beliefs are likely to color the juror's weighing of the evidence presented at the guilt phase of the trial. ${ }^{122}$

The Supreme Court's jurisprudence on voir dire into racial bias leaves us with the following general rules. A capital defendant charged with an interracial crime of

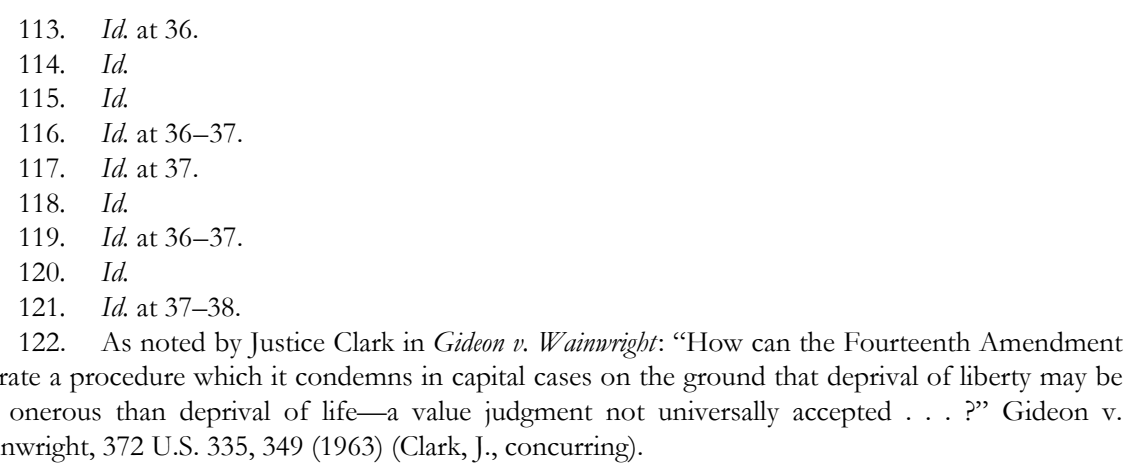


violence in either state or federal court has a due process right to have prospective jurors questioned on racial bias, but the defendant must specifically request such voir dire in order to trigger the constitutional right. ${ }^{123}$ A noncapital defendant has a constitutional right to have prospective jurors questioned on racial bias only if the circumstances of the case suggest a significant likelihood of prejudice by the jurors. ${ }^{124}$ The mere fact that the defendant and victim are of different races is not considered a special circumstance triggering the due process right to voir dire into racial bias. ${ }^{125} \mathrm{~A}$ federal court overseeing a case involving a defendant charged with an interracial crime of violence should, as a prudential matter, allow the defense to question prospective jurors on racial bias as long as the defendant requests such voir dire. ${ }^{126}$ The States of course are free to go further than the constitutional minimums set forth by the Supreme Court.

All of the Supreme Court cases on voir dire into racial bias to date have focused on whether the defendant has a right to such voir dire. The Court has never addressed the question of whether the government has a corresponding right to have prospective jurors questioned on racial bias. In certain cases, particularly in interracial cases involving a White defendant and a Black victim, the prosecutor may be concerned that racial stereotypes may lead jurors to sympathize with the defendant and have less empathy for the victim. Racial stereotypes about Black men as dangerous, violent criminals may encourage jurors to see the victim's actions as threatening and the defendant's actions as reasonable.

In perhaps the only law review article to focus on this question, Tania Tetlow argues that the Supreme Court should establish that the prosecutor shares the defendant's constitutional right to conduct voir dire into racial bias. ${ }^{127}$ "Tetlow notes that prosecutors are charged with "doing justice," and argues that "doing justice" includes ensuring equal protection of the law for defendants and victims alike. ${ }^{128}$ One way to ensure equal protection for victims of color, Tetlow argues, is to allow prosecutors to question prospective jurors on racial bias so they can better ascertain which individuals can serve as truly impartial jurors. ${ }^{129}$ Tetlow argues that the right to voir dire into racial bias should not be limited to capital cases in which the defendant is charged with an interracial crime of violence and cases involving a significant likelihood of prejudice in the jurors. ${ }^{130}$ Although it is difficult to make a case for a constitutional right to voir dire into racial bias for prosecutors, I agree that as a prudential matter, courts should permit prosecutors as well as defense

123. Turner, 476 U.S. at 36-37.

124. Ristaino v. Ross, 424 U.S. 589, 596-97 (1976).

125. Id.

126. Rosales-Lopez v. United States, 451 U.S. 182, 192 (1981).

127. Tania Tetlow, Granting Prosecutors Constitutional Rights to Combat Discrimination, 14 U. PA. J. CONST. L. 1117 (2012).

128. Id. at 1125-26 ("Doing battle against discriminatory acquittal falls squarely within a prosecutor's ethical duty to 'do justice' ....”').

129. Id. at $1148-51$.

130. Id. at $1151-52$. 
attorneys to conduct voir dire into racial bias in any case in which racial stereotypes may influence the jury.

\section{SOCIAL SCIENCE RESEARCH ON RACE SALIENCE}

\section{A. Implicit Bias}

Over the past decade, social scientists have convincingly demonstrated that bias is largely unconscious and often at odds with conscious beliefs. ${ }^{131}$ Even though one may sincerely believe that all individuals should be treated equally regardless of race, one may nonetheless have an implicit preference for individuals of one race over individuals of another race. This type of bias that exists outside of conscious awareness is called "implicit bias."

Social scientists have demonstrated that most Americans are affected by implicit bias through an online test known as the Implicit Association Test (IAT). The IAT measures the amount of time that an individual takes to associate different words and images viewed on a computer screen. ${ }^{132}$ When individuals are asked to pair words and images and those pairings are consistent with widely held beliefs and attitudes, their response times are fairly quick. ${ }^{133}$ When they are asked to pair words and images that do not correlate to widely held associations, response times are noticeably slower. ${ }^{134}$ For example, individuals asked to pair names like Katie and Meredith with words or images reflecting pleasant and nice things and names like Ebony and LaTonya, names associated with African Americans, with words or images reflecting unpleasant or negative things were able to do this task fairly quickly. ${ }^{135}$ When they were asked to pair White-sounding names with unpleasant or negative words and images and African American sounding names with pleasant or positive words and images, their response times were noticeably slower. ${ }^{136}$ Since I have written at length about implicit bias in previous works, I will not repeat that discussion here. ${ }^{137}$

Over fourteen million IATs, measuring bias based on age, gender, sexuality, among other types of biases, have been taken. ${ }^{138}$ IAT research has shown that both young and old individuals tend to favor the young and disfavor the elderly. ${ }^{139}$ Most

131. Laurie A. Rudman et al., "Unlearning" Automatic Biases: The Malleability of Implicit Prejudice and Stereotypes, 81 J. PERSONALITY \& SOC. PSYCHOL. 856, 856 (2001).

132. Jerry Kang, Trojan Horses of Race, 118 HARV. L. REV. 1489, 1509-10 (2005).

133. Jerry Kang et al., Implicit Bias in the Courtroom, 59 UCLA L. REV. 1124, 1130 (2012).

134. Id.

135. Anthony G. Greenwald et al., Measuring Individual Differences in Implicit Cognition: The Implicit Association Test, 74 J. PERSONALITY \& SOC. PSYCHOL. 1464, 1465-68 (1998).

136. Id. at 1469-70.

137. See Lee, supra note 15, at 1570-72 (2013); Cynthia Lee, The Gay Panic Defense, 42 U.C. DAVIS L. REV. 471, 536-49 (2008).

138. MAHZARIN R. BANAJi \& ANTHONy G. GREENWALD, BlindsPot: Hidden Biases of GOOD PEOPLE 69 (2013).

139. Becca R. Levy \& Mahzrin R. Banaji, Implicit Ageism, in AgEISM: STEREOTYPING AND Prejudice AgAinst OlDER Persons 49, 55 (Todd D. Nelson ed., 2002). Indeed, researchers have 
heterosexuals taking the sexual orientation IAT have demonstrated an implicit bias in favor of heterosexuals over gays and lesbians. ${ }^{140}$ Of those who have taken the race IAT, seventy-five percent have demonstrated implicit bias in favor of Whites over Blacks. ${ }^{141}$

\section{B. Race Salience}

In light of the research on implicit bias, social scientists have studied whether race salience can encourage individuals to overcome their implicit racial biases. "Race salience" is a term of art used by some social scientists to refer to the process of making salient the potential for racial bias. ${ }^{142}$ "Race salience" does not simply refer to juror awareness of the races of the defendant and victim. ${ }^{143}$ It involves "“making salient' the potential racism of jurors' attitudes."144

A wealth of fairly recent empirical research has shown that when race is made salient either through pretrial publicity, voir dire questioning of prospective jurors, opening and closing arguments, or witness testimony, White jurors are more likely to treat similarly situated Black and White defendants the same way. ${ }^{145}$ For example, in one study, Steven Fein and others examined the effects of pretrial publicity on mock jurors. ${ }^{146}$ The study found that most mock jurors were negatively influenced by newspaper articles that presented the facts in a way that disfavored the defendant, even when the mock jurors were told that the newspaper articles were inadmissible and should not be considered in deciding the defendant's guilt. ${ }^{147}$ However, when mock jurors were given information suggesting that the media's treatment of the defendant was racially biased, the negative bias against the defendant that the mock jurors had previously exhibited disappeared. ${ }^{148}$

In another experiment conducted by Samuel Sommers and Phoebe Ellsworth, jury-eligible citizens and actual jury pool members from a county in Michigan were

found that implicit ageism or implicit bias against the elderly is even more prevalent than implicit racial bias against Blacks. Id. at $54-55$.

140. Brian A. Nosek et al., Pervasiveness and Correlates of Implicit Attitudes and Stereotypes, 18 EuR. REV. SOC. PSYCHOL. 1, 19 (2007) (finding that sixty-eight percent of study participants showed an implicit preference for straight people over gay people).

141. BANAJI \& GREENWALD, supra note 138, at 47.

142. Samuel R. Sommers \& Phoebe C. Ellsworth, "Race Salience" in Juror Decision-Making: Misconceptions, Clarifications, and Unanswered Questions, 27 BEHAV. SCI. \& L. 599, 601 (2009).

143. Id. at 603-05.

144. Id. at 601 .

145. Id.

146. Steven Fein et al., Hype and Suspicion: The Effects of Pretrial Publicity, Race, and Suspicion on Jurors' Verdicts, 53 J. SOC. Issues 487 (1997).

147. Id. at 497 ("Exposure to pretrial publicity that reported incriminating information about the defendant made our mock jurors more likely to reach guilty verdicts than the mock jurors in the control condition.”).

148. Id. ("The notable exception concerns mock jurors who received the incriminating pretrial publicity along with other publicity designed to make them suspect that the incriminating information may have been released to the public because of racist motives."). 
shown a videotaped summary of an actual rape trial involving a Black defendant. ${ }^{149}$ Participants completed a voir dire questionnaire, watched a trial video, received actual State of Michigan pattern jury instructions, and deliberated on the case as members of six-person juries. ${ }^{150}$ Although all the mock jurors viewed the same trial video, some received questions about their racial attitudes and general perceptions of racial bias in the legal system on their voir dire questionnaire while other mock jurors did not. ${ }^{151}$ For example, some mock jurors read the following race-relevant question: "The defendant in the case is African-American and the victims are White. How might this affect your perceptions of the trial?"152 Another race-relevant question was: "In your opinion, how does the race of a defendant influence the treatment $\mathrm{s} /$ he receives in the legal system as a whole?"153

Sommers and Ellsworth found that regardless of their race, mock jurors who received the race-relevant voir dire questions were less likely to vote to convict the Black defendant than the mock jurors who did not receive race-relevant voir dire questions. ${ }^{154}$ It is worth noting that the race relevant questions were not intended to identify jurors likely to exhibit racial bias in their judgments. ${ }^{155}$ Rather, they were "designed to force mock jurors to think about their racial attitudes and, more generally, about social norms against racial prejudice and institutional bias in the legal system."156

Calling attention to the possibility of racial bias through witness testimony can also help minimize racial bias. In another study, Ellen Cohn and others found that White mock jurors were less likely to convict a Black defendant charged with attempted vehicular manslaughter after striking three White men with his car if presented with testimony from the defendant's wife revealing that the White victims shouted racial slurs at the defendant and his wife before the defendant got into his vehicle and sped away. ${ }^{157}$ Calling attention to the possibility that the victims may have been racially biased against the defendant may have encouraged the jurors to consider the facts with a bit more empathy for the defendant than they otherwise might have had.

Racial bias can also be reduced if race is made salient by attorneys in their opening and closing statements. Donald Bucolo and Ellen Cohn found that when a defense attorney called attention to the possibility of racial bias in his opening and closing statements, White mock jurors were less likely to find the Black male

149. Samuel R. Sommers \& Phoebe C. Ellsworth, How Much Do We Really Know About Race and Juries?: A Review of Social Science Theory and Research, 78 CHI.-KENT L. REV. 997, 1026 (2003).

150. Id.

151. Id.

152. Id. at 1027 .

153. Id.

154. Id.

155. Id.

156. Id.

157. Ellen S. Cohn et al., Reducing White Juror Bias: The Role of Race Salience and Racial Attitudes, 39 J. APPLIED SOC. PSYCHOL. 1953, 1959, 1964 (2009). 
defendant guilty of assault and battery than when the attorney did not call attention to the possibility of racial bias in his opening and closing statements. ${ }^{158}$ Statements making race salient included, "The defendant did what any (Black/White) man in this situation would do," and "The only reason the defendant, and not the supposed victim, is being charged with this crime is because the defendant is (Black/White) and the victim is (White/Black)." 159 Bucolo and Cohn concluded that highlighting race in an interracial trial was a beneficial defense strategy when the defendant was Black, "leading to decreased ratings of guilt."'160

\section{SoCIAL SCIENCE RESEARCH ON RACIAL PERCEPTIONS OF CRIME AND Support for Punitive Criminal Justice Policies}

Some recent social science research on racial perceptions of crime and support for punitive polices calls into question whether making race salient is a good idea. In 2014, Rebecca Hetey and Jennifer Eberhardt published the results of experiments they conducted in San Francisco and New York City. ${ }^{161}$ In each experiment, they manipulated the racial composition of the prison population and then measured the subject's support for or acceptance of a punitive criminal justice policy. ${ }^{162}$ They found that when the prison population was represented as more Black, participants were more supportive of punitive criminal justice policies. ${ }^{163}$

In the first experiment, Hetey and Eberhardt tested support for California's Three Strikes Law. ${ }^{164}$ This law, passed in 1994, mandated a twenty-five-years-to-life prison sentence for anyone convicted of a felony after having been convicted of two prior violent or serious felonies. ${ }^{165}$ Even a minor third felony such as "stealing a dollar in loose change from a parked car" could result in a life sentence under the Three Strikes Law as originally enacted. ${ }^{166}$ In 2012, critics of the Three Strikes Law sought to amend it by permitting a twenty-five-years-to-life sentence only if the defendant's third felony was a serious or violent felony. ${ }^{167}$ The proposed amendment would appear on the November 2012 ballot only if enough signatures supporting the amendment were gathered. ${ }^{168}$

In the experiment, a White female recruited registered California voters from

158. Donald O. Bucolo \& Ellen S. Cohn, Playing the Race Card: Making Race Salient in Defence Opening and Closing Statements, 15 LEGAL \& CRIMINOLOGICAL PSYCHOL. 293, 297, 299 (2010).

159. Id. at 297.

160. Id. at 299 .

161. Rebecca C. Hetey \& Jennifer L. Eberhardt, Racial Disparities in Incarceration Increase Acceptance of Punitive Policies, PSYCHOL. SCI. 1-6 (2014).

162. Id. at 1.

163. Id.

164. Id. at 2.

165. Id.

166. Id.

167. Id.

168. Id. The ballot initiative, California Proposition 36, did appear on the November 2012 ballot and passed. STANFORD JUSTICE ADVOCACY PROJECT, https://law.stanford.edu/stanford-justiceadvocacy-project/ [https://perma.cc/F9CE-Y8NZ] (last visited Sept. 16, 2015). 
a San Francisco Bay Area commuter station to participate in the study, which was described to them as exploring Californians' views on social issues. ${ }^{169}$ Participants, all of whom were Caucasian, were shown eighty color photographs of Black and White inmates on an iPad. ${ }^{170}$ Some participants were shown fewer Black faces than other participants. ${ }^{171}$ In the "less Black" condition, only twenty-five percent of the photographs were of Black inmates, which was about the same percentage of Blacks actually in California prisons. ${ }^{172}$ In the "more Black" condition, forty-five percent of the photographs were of Black inmates, reflecting the approximate percentage of Blacks incarcerated under California's Three Strikes Law. ${ }^{173}$ Next, the subjects were informed of California's Three Strikes Law and the initiative to amend it. ${ }^{174}$ Subjects were asked to rate how punitive they thought the Three Strikes Law was. ${ }^{175}$ The subjects were then told the study was over and that the experimenter had copies of the actual petition, which they could look at and sign if they wanted. ${ }^{176}$ Subjects were told that if they signed the petition, their signature would be forwarded to the State Attorney General's office to be counted.177

Hetey and Eberhardt found that regardless of the condition they were in ("more Black" or "less Black"), subjects across the board agreed that California's Three Strikes Law was too punitive rather than not punitive enough. ${ }^{178}$ Subjects in the "less Black" condition, however, were much more willing to sign the petition to amend the law to require that the third felony conviction be a serious or violent felony than subjects in the "more Black" condition. ${ }^{179}$ Of the participants who saw fewer photos of Black inmates, $51.72 \%$ signed the petition, whereas only $27.27 \%$ of participants who saw more photos of Black inmates signed the petition. ${ }^{180}$ Hetey and Eberhardt concluded that the Blacker the participant believed the prison population to be, the less willing the participant was to amend a law they acknowledged was overly punitive. ${ }^{181}$

Hetey and Eberhardt conducted a second study (Study 2) in New York City, this time testing support for New York City's controversial stop-and-frisk policy. ${ }^{182}$ The researchers recruited White New York City residents to complete an online survey in October 2013. ${ }^{183}$ Instead of showing participants photos of inmates, they

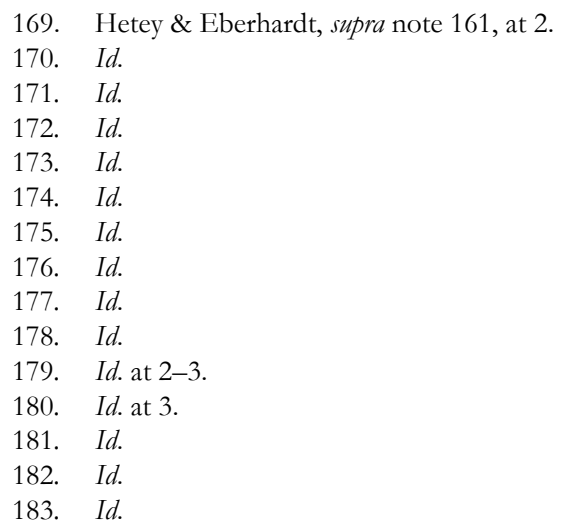


simply presented participants with statistics about the prison population. ${ }^{184}$ In the "less Black" condition, they told subjects that the prison population was $40.3 \%$ Black and $31.8 \%$ White, which was almost the actual percentage of Blacks in prisons across the nation. ${ }^{185}$ In the "more Black" condition, they told subjects that the prison population was $60.3 \%$ Black and $11.8 \%$ White, approximately the actual percentage of Black inmates in New York City Department of Corrections facilities. ${ }^{186}$ Next, participants were told that a federal judge had ruled that New York's stop-and-frisk policy was unconstitutional (this was actually true) and that the city was appealing the judge's ruling. ${ }^{187}$ Participants were then asked a series of questions designed to measure their support for keeping New York's stop-and-frisk policy. ${ }^{188}$ Finally, participants were asked whether they would sign a petition to end New York City's stop-and-frisk policy. ${ }^{189}$

Hetey and Eberhardt found that regardless of what condition they were in, participants across the board felt that New York's stop and frisk policy was "somewhat punitive."190 Participants in the "more Black" condition, however, were "significantly less willing to sign a petition to end the stop-and-frisk policy than were participants in the less-Black condition." 191 Only $12.05 \%$ of participants in the "more Black" condition said they would sign the petition compared to $33.3 \%$ in the "less Black" condition. ${ }^{192}$

Also in 2014, The Sentencing Project published a report entitled, Race and Punishment: Racial Perceptions of Crime and Support for Punitive Policies. ${ }^{193}$ The Sentencing Project found that skewed racial perceptions of crime by White Americans bolster their support for harsh criminal justice policies. ${ }^{194}$ Synthesizing two decades of research, ${ }^{195}$ The Sentencing Project reported that White Americans consistently overestimate the proportion of crime committed by persons of color. ${ }^{196}$ The report theorized that attributing crime to racial minorities limits White Americans' ability to empathize with offenders and encourages retribution as the primary response to crime. ${ }^{197}$ The result: increased support for punitive criminal justice policies.

One might conclude that this recent research on racial perceptions of crime

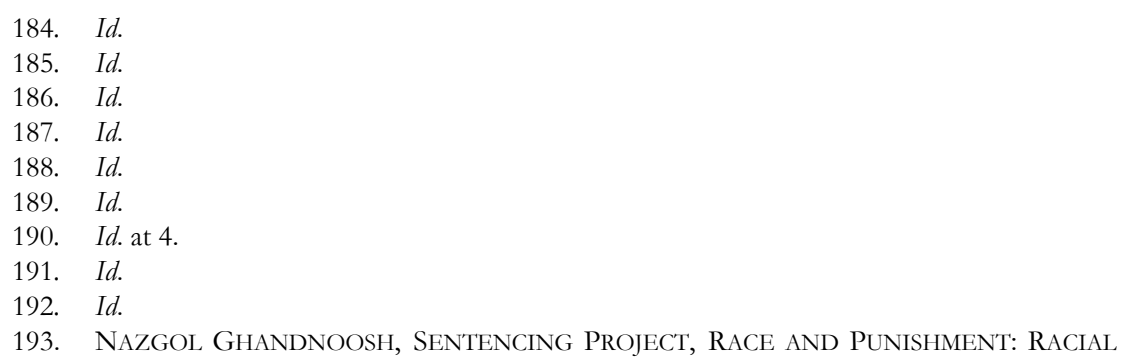
Perceptions OF CRIME AND Support FOR Punitive POlicies (2014), http:// sentencingproject.org/doc/publications/rd_Race_and_Punishment.pdf [http://perma.cc/R4HHGVRC].

194. Id. at 5.

195. Id. at 3 .

196. Id. at 5,13 .

197. Id. at 6,18-19. 
leading to increased support for punitive policies means that calling attention to race is a bad idea as it may simply remind jurors of the association between Black and crime and encourage White jurors to act more punitively towards Black defendants. The research, however, does not support such a conclusion. Recall that The Sentencing Project's report identified skewed or inaccurate racial perceptions of crime as the problem. ${ }^{198}$ Similarly, Hetey and Eberhardt's Three Strikes study suggested that when individuals believed there were more Blacks in prison than might actually be the case, they were more supportive of punitive criminal justice policies. ${ }^{199}$ Indeed, the Sentencing Project explicitly supports making race salient, noting that " $[\mathrm{m}]$ ock jury studies have shown that increasing the salience of race in cases reduces bias in outcomes by making jurors more conscious of and thoughtful about their biases." 200 Making race and the possibility of racial bias salient, as opposed to highlighting extreme racial disparities in the prison population, can help reduce bias in jurors by encouraging them to think about and counter their own biases.

Implicit racial bias — unconscious racial bias even among people who explicitly disavow racial prejudice-contributes to inaccurate perceptions of race and crime because it encourages individuals to associate all or most Blacks and Latinos with crime when only some Blacks and Latinos are engaging in criminal behavior. ${ }^{201}$ One way to overcome implicit racial bias is to recognize its existence. "Dispelling the illusion that we are colorblind in our decision making is a crucial first step to mitigating the impact of implicit racial bias." 202

\section{COMBATING IMPLiCIT RACIAL BIAS IN THE CRIMINAL COURTROOM}

In light of the social science research on implicit bias, what steps can be taken to combat implicit racial bias in the criminal courtroom? This Section discusses a few different ways to address the problem of implicit bias in the courtroom. While the focus of this Article is on combating racial bias, the proposals discussed within can be helpful to attorneys concerned about bias of any kind. ${ }^{203}$

\section{A. Raising Awareness of Implicit Bias Through Jury Orientation Materials}

As Carol Izumi notes, "Awareness of bias is critical for mental decontamination success." 204 If so, then making sure jurors know what implicit bias

198. Id. at 3,5 .

199. Hetey \& Eberhardt, supra note 161, at 2.

200. GHANDNOOSH, supra note 193, at 39 .

201. Id. at 14 .

202. Id. at 39 .

203. For an excellent discussion on the difficulties of conducting voir dire when the concern is bias against gays, lesbians, and other sexual minorities, see Giovanna Shay, In the Box: Voir Dire on LGBT Issues in Changing Times, 37 HARV. J.L. \& GENDER 407 (2014).

204. Carol Izumi, Implicit Bias and the Illusion of Mediator Neutrality, 34 WASH. U. J.L. \& POL'Y 71, 141 (2010) (citing Laurie A. Rudman et al., "Unlearning” Automatic Biases: The Malleability of Implicit Prejudice and Stereotypes, 81 J. PERSONALITY \& SOC. PSYCHOL. 856 (2001)). 
is and that they are likely to be affected by it is critical. Anna Roberts suggests one way to make jurors aware of the concept of implicit bias: include discussion of implicit bias in juror orientation materials. Roberts argues that including information about implicit bias in jury orientation materials, particularly jury orientation videos, makes sense for several reasons. ${ }^{205}$ First, information on implicit bias dovetails nicely with appeals to neutrality and egalitarian norms that are usually imparted to jurors during jury orientation. ${ }^{206}$ Second, "impressions formed early on can shape the understanding of what follows." 207 If a juror is made aware of implicit bias early on, she can better guard against it influencing her own decision making. Third, addressing implicit bias during jury orientation insures that all prospective jurors are educated about it, not just those who serendipitously end up with a judge who believes it important to mention the topic. ${ }^{208}$ Roberts goes further, suggesting not only that prospective jurors be informed about implicit bias during jury orientation but also that they should also be encouraged to take the IAT so they can experience bias within themselves. ${ }^{209}$ Although there is some research that suggests being forced to take diversity training leads to backlash and resistance, ${ }^{210}$ this research does not undermine Roberts' proposal because Roberts does not suggest that courts require all prospective jurors to take the IAT. She would merely have courts encourage prospective jurors to take the IAT on a voluntary basis. ${ }^{211}$

\section{B. Raising Awareness of Implicit Bias Through Voir Dire}

Voir dire on the topic of racial bias offers another way to make jurors aware of the concept of implicit bias. As discussed above, a wealth of social science research suggests that making race salient or calling attention to the possibility of racial bias can encourage prospective jurors to reflect on their own possible biases and consciously counter what would otherwise be automatic stereotype-congruent responses. Voir dire offers an opportunity to make race salient to prospective jurors.

Questions designed to explore the subject of racial bias through voir dire would have to be carefully formatted. Open-ended questions that encourage reflection and thought about the powerful influence of race would be better than close-ended questions that simply encourage the prospective juror to give the politically correct response. ${ }^{212}$ Open-ended questions in general offer prospective

205. Anna Roberts, (Re)forming the Jury: Detection and Disinfection of Implicit Juror Bias, 44 CONN. L. REV. 827, 863-65 (2012).

206. Id. at 863 .

207. Id. at 864 .

208. $I d$.

209. Id. at $867-71$.

210. See Rudman et al., supra note 204, at 857 (noting that involuntary diversity training has not been effective), 861 (noting that students who voluntarily enrolled in a diversity education seminar showed less implicit and explicit anti-Black bias at the end of the semester compared to students who did not take the class).

211. Roberts, supra note 205 , at 874 ("The IAT would be optional . . ..").

212. Regina A. Schuller et al., The Impact of Prejudice Screening Procedures on Racial Bias in the Courtroom, 33 LAW \& HUM. BEHAV. 320, 326 (2009). 
jurors the chance to reflect and comment. Open-ended questions on racial bias in particular can give the attorney much more valuable information about which prospective jurors are likely to try to overcome their implicit biases than close-ended questions in which the juror is prompted to give a short "yes" or "no" response. 213

Jonathan Rapping, President and founder of Gideon's Promise, ${ }^{214}$ offers several examples of effective voir dire strategies for an attorney concerned about racial bias. ${ }^{215}$ Rapping suggests that an attorney could start with the following:

You have just learned about the concept of [implicit racial bias]. Not everyone agrees on the power of its influence or that they are personally susceptible to it. I'd like to get a sense of your reaction to the concept of subconscious racial bias and whether you are open to believing it may influence you in your day-to-day decision-making. Let me start by asking for your reaction to learning about the idea of implicit, or subconscious, racial bias. ${ }^{216}$

If a prospective juror expresses skepticism about implicit racial bias, Rapping recommends that the attorney respond as follows: "I appreciate your candor and thank you for sharing this view ... it is certainly not an uncommon reaction to first learning about [implicit racial bias] . . . [D]o others share Juror Number X's skepticism?"'217

The attorney concerned about implicit racial bias will also want to find out which prospective jurors are motivated to act in egalitarian ways since social science research suggests that egalitarian-minded individuals are more likely than hierarchical individuals to try to counteract stereotypical thinking when made aware of the possibility of racial bias. ${ }^{218}$ To find out which individuals are motivated to act in egalitarian ways, Rapping cautions attorneys not to ask questions like "How do you feel about racism?" or "Do you believe it is ever appropriate to judge someone based on their skin color?" because prospective jurors may answer such questions by simply giving what they believe to be the socially desirable response. ${ }^{219}$ Rapping suggests that the attorney instead ask prospective jurors to "[d]escribe [their] most significant interaction(s) with a member of another race" or "[d]escribe a particularly impactful interaction that [they or someone close to them] had with a member of another race." 220 Such questions force the prospective jurors to think

213. Id. at 326 .

214. Founded by Jonathan Rapping, Gideon's Promise is a nonprofit organization that provides comprehensive advocacy training and community building support for both entry-level and seasoned public defenders. See FAQs, GIDEON's PROMISE, http://gideonspromise.org/faqs/ [http://perma.cc/K9Z5-7FP5] (last visited Sept. 16, 2015).

215. Jonathan A. Rapping, Implicitly Unjust: How Defenders Can Affect Systemic Racist Assumptions, 16 N.Y.U. J. LEGIS. \& PUB POL'Y 999, 1032 (2013).

216. $I d$.

217. Id. at 1033 .

218. Patricia G. Devine, Stereotypes and Prejudice: Their Automatic and Controlled Components, $56 \mathrm{~J}$. PERSONALiTy \& SOC. PSYCHOL. 5, 14-15 (1989).

219. Rapping, supra note 215 , at 1034.

220. Id. 
about how they felt or acted in an actual situation as opposed to discussing how they think they would act in a hypothetical situation. ${ }^{221}$ This is important because "people often aspire to act in ways that do not perfectly match how they have behaved in the past." 222 As Rapping notes, "The best predictor of what a person will do in the future is not what they say they will do, but what they have done in the past in analogous situations." 223 An attorney might also ask a prospective juror to discuss "the best ... experience the [prospective] juror has had with a member of another race" or ask the prospective juror to identify a member of another race whom the prospective juror admires. ${ }^{224}$ Such questions track the social science research on debiasing. This research indicates that encouraging people to think about admired African American figures, such as Barack Obama, Colin Powell, and Martin Luther King, and disfavored White individuals, such as Jeffrey Dahmer (the infamous serial killer also known as the Milwaukee Cannibal), Ted Kaczynski (the Unabomber), and Timothy McVeigh (the man responsible for the 1995 Oklahoma City bombing), can help jurors counter the impulse to associate Blacks with criminality. 225

\section{Possible Objections}

My proposal that attorneys concerned about implicit racial bias use voir dire to counter the automatic stereotype-congruent associations that most individuals make based on race is likely to encounter resistance on a number of fronts. One possible objection echoes the concerns raised by Albert Alschuler several decades ago. Alschuler opined that voir dire into racial bias would be "minimally useful"226 because any prospective juror asked whether he would be prejudiced against the defendant because of the defendant's race would find such a question patronizing

221. Id. Such questions could also force prospective jurors to think about whether they have ever had a significant interaction with a member of another race, which could also have a positive effect.

222. Id.

223. Id. (quoting Ira Mickenberg, Voir Dire and Jury Selection, NORTH CAROLINA DEFENDER TRIAL SCHOOL 6 (2011), http://www.ncids.org/Defender\%20Training/2011DefenderTrialSchool/ VoirDire.pdf).

224. Id. at 1035. Rapping suggests that the attorney should also ask the prospective juror to discuss negative experiences with members of another race and times that the juror relied on a stereotype that turned out to be wrong. $I d$. Reminding prospective jurors of negative experiences with members of another race, however, may trigger negative stereotypes, so I would focus on encouraging jurors to think about positive experiences with members of other racial groups and admired individuals belonging to the racial group in question.

225. Nilanjana Dasgupta \& Anthony G. Greenwald, On the Malleability of Automatic Attitudes: Combating Automatic Prejudice with Images of Admired and Disliked Individuals, 81 J. PERSONALITY \& SOC. PSYCHOL. 800, 803-05 (2001) (finding that exposure to famous admired Black individuals and infamous disfavored White individuals lead to a reduction in automatic pro-White preferences); Jennifer A. Joy-Gaba \& Brian A. Nosek, The Surprisingly Limited Malleability of Implicit Racial Evaluations, 41 SOC. PSYCHOL. 137 (2010) (finding that exposure to admired Blacks and disliked Whites resulted in a weaker automatic preference for Whites, but exposure to admired Blacks and admired Whites did not reduce automatic preference for Whites).

226. Alschuler, supra note 12. 
and offensive. 227 Alschuler suggested such voir dire would be akin to saying, "Pardon me. Are you a bigot?"228

Alschuler's objection, however, is not responsive to my proposal since I do not encourage attorneys to ask prospective jurors whether they will be prejudiced against the defendant on account of his race. I agree with Alschuler that a question like, "Are you likely to be biased against the defendant because of his race?" is unlikely to provoke an admission of bias. Individuals in today's society know that it is considered wrong to discriminate on the basis of race, so even an individual who might actually be biased against the defendant because of the defendant's race would almost surely answer such a question in the negative in order not to appear bigoted. Even an individual who truly disavows racism and racial discrimination might answer such a question in the negative, sincerely believing that he or she will not be biased against the defendant on account of the defendant's race, when social cognition research suggests that all individuals, even the most egalitarian-minded on explicit measures, are implicitly biased on the basis of race. ${ }^{229}$

I disagree, however, with Alschuler's claim that voir dire into racial bias would be "minimally useful" in cases involving racial issues. Voir dire into racial bias can and should take the form of encouraging prospective jurors to think about racial bias in general. As discussed above, making race salient, whether through witness testimony or questions asked during voir dire, can inhibit the automatic associations that otherwise are likely to come into play when the defendant, the victim, or a witness is a member of a racially stereotyped group. ${ }^{230}$

A second possible objection is more troubling and involves a burgeoning field of research on stereotype threat. As Song Richardson and Philip Atiba Goff explain, "[s]tereotype threat refers to the concern with confirming or being evaluated in terms of a negative stereotype about one's group." 231 Most of us are aware of the concept of stereotype threat from Claude Steele's research in the 1990s on African American undergraduate students faring poorly on standardized tests. ${ }^{232}$ Steele's research showed that anxiety about confirming the stereotype that links African Americans to lack of intelligence results in African Americans doing poorly on

227. Id. at 161 .

228. Id.

229. BANAJI \& GREENWALD, supra note 138, at 158-59. Sheri Lynn Johnson explains that "[a]sking a general question about impartiality and race is like asking whether one believes in equality for Blacks; jurors may sincerely answer yes, they believe in equality and yes, they can be impartial, yet oppose interracial marriage and believe that Blacks are more prone to violence." Sheri Lynn Johnson, Black Innocence and the White Jury, 83 MICH. L. REV. 1611, 1675 (1985). Johnson also explains that prospective jurors "would naturally be reluctant to admit [prejudiced attitudes], particularly since they know that social disapproval will be publicly expressed by dismissing them from the venire." Id.

230. See infra text accompanying notes 142-160.

231. L. Song Richardson \& Phillip Atiba Goff, Interrogating Racial Violence, 12 OHIO ST. J. CRIM. L. 115, 124 (2014).

232. Claude M. Steele \& Joshua Aronson, Stereotype Threat and the Intellectual Test Performance of African Americans, 69 J. PERSONALITY \& SOC. PSYCHOL. 797 (1995); see also Claude M. Steele, A Threat in the Air: How Stereotypes Shape Intellectual Identity and Performance, 52 AM. PSYCHOLOGIST 613 (1997). 
standardized tests. ${ }^{233}$ Subsequent research has confirmed that " $[\mathrm{t}]$ he concern with being negatively stereotyped often provokes anxiety, leading to physical and mental reactions that are difficult, if not impossible to volitionally control such as increased heart rate, fidgeting, sweating, averting eye gaze, and cognitive depletion-often leading to a reported inability to think clearly." 234

Stereotype threat affects not only African Americans, but also anyone who belongs to a group that is negatively stereotyped. For example, women as a group suffer from the stereotype of not being good at math. ${ }^{235}$ When women are reminded of this stereotype, they tend to perform worse on math tests than when they are not reminded of the stereotype. ${ }^{236}$ Stereotype threat afflicts not just members of historically disadvantaged groups; it has also been shown to afflict White police officers concerned with being seen as racist. ${ }^{237}$ In Interrogating Racial Violence, Song Richardson and Phillip Atiba Goff document a study involving police officers with the San Jose, California Police Department. ${ }^{238}$ Surprisingly, the officers most concerned with not being or appearing to be racist were found to be quicker to use physical force to control situations involving Black suspects than officers who were not as concerned with how they were perceived by others. ${ }^{239}$ To explain these findings, Richardson and Goff theorize that an officer who fears that a suspect sees him as racist will believe that he cannot rely on moral authority to control the situation, and thus must resort to physical force. ${ }^{240}$

If White police officers concerned about being seen as racist (i.e., officers concerned about the White-cop-as-racist stereotype) end up acting in more racially disparate ways than White police officers not so concerned about being seen as racist, should we worry that White jurors made aware of their own implicit biases

233. Steele \& Aronson, supra note 232.

234. Richardson \& Goff, supra note 231.

235. Laurie T. O'Brien \& Christian S. Crandall, Stereotype Threat and Arousal: Effects on Women's Math Performance, 29 PERSONALITY \& SOC. PSYCHOL. BulL. 782, 784 (2003) (noting the stereotype of male superiority in math).

236. Id. (finding that women who were told that the test they were going to take had been shown to produce gender differences did less well on math tests than women who were told that the test they were about to take had not been shown to produce gender differences); see also Paul G. Davies et al., Consuming Images: How Television Commercials That Elicit Stereotype Threat Can Restrain Women Academically and Professionally, 28 PERSONALITY \& SOC. PSYCHOL. Bull. 1615, 1624 (2002) (finding that women exposed to gender-stereotypic television commercials underperformed on the math portion of a nondiagnostic test); Steven J. Spencer et al., Stereotype Threat and Women's Math Performance, $35 \mathrm{~J}$. EXPERIMENTAL SOC. PSYCHOL. 4, 13 (1999) (finding that women who were told that the math test they were about to take was one in which gender differences do not occur performed just as well as men taking the same test, but women told that the test they were about to take was one in which gender differences had occurred performed worse than men taking the same test).

237. Richardson \& Goff, supra note 231, at 126 (describing study involving the use of force by police officers with the San Jose Police Department).

238. Id.

239. Id. (" $[\mathrm{T}]$ he more officers were concerned with appearing racist, the more likely they were to have used force against Black suspects, but not suspects of other races, throughout the course of their careers."').

240. Id. 
will become overly concerned with not appearing racist and end up acting in ways that disadvantage Black defendants and victims over White defendants and victims? While certainly possible, I do not think this is likely because there is no prevailing stereotype of the White racist juror whereas at least in some communities, there seems to be an existing stereotype of the White racist police officer. While certain communities may view White jurors with distrust, most Whites do not think of themselves as racist and, more importantly, do not think others generally view them as racist. Nonetheless, the research on stereotype threat suggests that attorneys attempting to raise awareness of implicit racial bias during voir dire must be careful not to trigger anxiety in prospective jurors that they might be seen as racist. ${ }^{241}$ Making jurors aware of their own implicit biases while not triggering stereotype threat is likely to be a difficult balancing act, somewhat like walking on a very thin tight rope.

\section{CONCLUSION}

In cases in which racial stereotypes about either the defendant, the victim, or a witness may influence the fact finder's assessment of who was at fault, it is important for attorneys concerned about minimizing the risk of racial bias to be aware of the social science research on race salience. This research suggests that calling attention to race can help reduce racial bias in legal decision making. Voir dire into racial bias offers one way an attorney can make race salient to the jury. Calling attention to race can help minimize racial bias by encouraging jurors to consciously think about the impropriety of racial stereotyping.

241. But see Phillip Atiba Goff et al., The Space Between Us: Stereotype Threat and Distance in Interracial Contexts, 94 J. Personality \& SOC. PSYCHOL. 91 (2008) (finding that White, male undergrad students at Stanford University reminded of the stereotype that Whites are racist and told that they would be discussing the subject of racial profiling with two partners positioned their chairs further away from their partners when they thought their partners would be Black than when they thought their partners would be White). 